\title{
UPAYA PENGELOLAAN PERAIRAN SUNGAI MUSI, SUMATERA UNTUK KEBERLANJUTAN PEMANFAATAN SUMBER DAYA IKAN
}

\author{
Ngurah Nyoman Wiadnyana, Husnah \\ Peneliti pada Balai Riset Perikanan Perairan Umum, Mariana-Palembang \\ Teregistrasi I tanggal: 30 Desember 2010; Diterima setelah perbaikan tanggal: 19 April 2011; \\ Disetujui terbit tanggal: 29 April 2011
}

\begin{abstract}
ABSTRAK
Pengelolaan sumber daya perairan Sungai Musi di Sumatera bertujuan untuk menjaga keberlanjutan pemanfaatan dan kelestarian sumber daya perairan di masa datang. Untuk itu diperlukan gambaran status terkini sumber daya perairan yang merupakan salah satu komponen yang diperlukan dalam pengelolaan. Perubahan pemanfaatan lahan selama periode 30 tahun di Daerah Aliran Sungai (DAS) Musi tampak berupa perubahan fisik (modifikasi lingkungan) dan penambahan bahan-bahan antropogenik. Modifikasi lingkungan yang terjadi seperti pembendungan sungai untuk pembangkit listrik tenaga air dan irigasi pada bagian hulu Sungai Musi, dan pembelokan masa air di anak Sungai Musi berdampak terhadap berkurangnya luas rawa banjiran, sedimentasi, penurunan debit air dan tinggi muka air, serta terhalangnya migrasi beberapa jenis ikan. Penambahan bahan-bahan antropogenik yang berasal dari berbagai kegiatan industri di bagian tengah dan hilir Sungai Musi, mempengaruhi sumber daya perairan dan ikan, serta hasil tangkapan nelayan. Berdasarkan indikator biota dasar makrozoobenthos dan ikan, Sungai Musi bagian hilir dari desa kelurahan Gandus sampai dengan Muara Sungai Komering tergolong tercemar berat oleh bahan organik. Pengelolaan sumber daya di perairan Sungai Musi perlu dilakukan untuk menjaga kelestarian dan keberlanjutan pemanfaatan sumber daya ikan perairan Sungai Musi di masa yang akan datang. Keragaman tipe ekosistem perairan, sifat pemanfatan yang multi guna dan multi sektor serta keberadaan wilayah Sungai Musi yang lintas provinsi merupakan komponen penting yang perlu dipertimbangkan dalam pengelolaan sumber daya perairan Sungai Musi. Pengelolaan sumber daya perairan di Sungai Musi hendaknya dilakukan secara terpadu dan holistik dengan mempertimbangkan beberapa aspek seperti wilayah/ ekologi, sektor, bidang ilmu dan stakeholder.
\end{abstract}

KATAKUNCI: kelestarian sumber daya perairan, pemantaatan berkelanjutan, upaya pengelolaan, Sungai Musi, Sumatera

\section{ABSTRACT: The effort of Musi River waters management in Sumatra for sustainable use of fish resources. By: Ngurah N. Wiadnyana and Husnah}

Water resource management of Musi River in Sumatra is aimed to assure the sustainable use and the sustainability of water resources in the future. Therefore it is needed the information of the current state of water resources as one of components required in management. The change of territorial use for a period of 30 years in Musi River Bank is appreared as form of a physical change (environment modification) and an increase of antrophogenic matters. The environment modification was such as a river barrier man-made used for water electricity power and irrigation at upper part of Musi River, and the turning water mass in Musi River, gives an impact to the decreasing of floodplain area, sedimentation, decrease of water debit and water level as well as the pertubation of some fishes migration. The augmentation of antrophogenic matters comming 


\begin{abstract}
from industrial activities in the central and down parts of Musi Rivers gives influence on water resources, fish, and the catch yield of fishermen. Based on macrozoobenthos bioindicators and fish, a down part of Musi River from Gandus Village to mouth of Komering River are classified as happy polluted areas by organic matter. The resources management of Musi River waters must be needed to be done for maintain the sustainability and the sustainable use of fish resources in Musi River in the future. The diversity of waters ecosystem, multi uses, and multi sectors as well as Musi River areas located across the several provinces, constitute important components to be needed to look together in managing Musi River water resources. The water resources management of Musi River should be done by integrated way and holistic with regard of some aspects such as: territorial/ ecology, sectors, expertises, and stakeholders.
\end{abstract}

KEYWORDS: $\quad$ sustainability of water resources, sustanable use, management effort, Musi River, Sumatra

\section{PENDAHULUAN}

Kekayaan alam yang dilimpahkan oleh Sang Pencipta untuk kemaslahatan umat manusia patut disyukuri dan mendapat perhatian dari semua pihak agar tetap terjaga dan terkelola dengan baik. Penyelerasan berbagai kepentingan harus menjadi dasar dalam penataan ruang perairan maupun daratan yang berhubungan langsung dengan perairan. Adanya konflik kepentingan dalam pembangunan sektor atau sub-sektor yang sering terjadi di berbagai tempat dapat menimbulkan kerugian besar pada ekosistem perairan, khususnya perairan umum. Sebagai langkah pengelolaan diperlukan upaya bersama dalam bentuk saling menjaga ataupun memperhatikan dampak negatif dari setiap pembangunan dari masingmasing sektor atau sub-sektor sesuai dengan Undang-Undang No. 7 tahun 2004 tentang Sumber daya Air.

Sungai Musi merupakan salah satu jenis ekosistem perairan umum daratan dengan panjang sungai yang dapat dilayari kurang lebih mencapai $700 \mathrm{~km}$ (Depkimpraswil, 2003). Luas Daerah Aliran Sungai (DAS) Musi sekitar 2,5 juta ha atau sekitar $20 \%$ dari seluruh luas perairan sungai dan lebak sebesar 12,5 juta ha (Manggabarani, 2005; Sukadi, 2005).
Sebagai bagian dari ekosistem perairan umum daratan di Pulau Sumatera, Sungai Musi bersifat multiguna dan memiliki peran strategis dalam mendukung pembangunan perekonomian masyarakat di daerah Sumatera Selatan.

Pentingnya peran Sungai Musi tercatat secara historis sejak zaman Kerajaan Sriwijaya. Pada saat itu, Sungai Musi banyak digunakan sebagai alur pelayaran kapal-kapal yang mengangkut hasil bumi menuju pusat-pusat perdagangan baik di wilayah Sumatera Selatan maupun ke luar daerah ke seluruh Sumatera dan pulaupulau luar Sumatera. Sampai saat ini Sungai Musi masih dimanfaatkan oleh berbagai sektor seperti pertanian, perikanan, perhubungan, perindustrian, kehutanan, perkebunan, pemukiman yang kesemuanya itu akan berdampak pada ekosistem perairan.

Dampak yang ditimbulkan oleh kegiatan berbagai sektor terhadap lingkungan dapat berbentuk perubahan fisik lingkungan perairan atau modifikasi lingkungan, atau penambahan bahan-bahan luar hasil kegiatan manusia (bahan-bahan antropogenik) baik yang bersifat beracun ataupun tidak beracun. Dampak yang ditimbulkan diantaranya adalah penurunan pada kualitas fisik dan kimia lingkungan perairan dan Kelimpahan dan 
keanekaragaman sumber daya hayati perairan. Kelimpahan dan keanekaragaman hayati pada suatu perairan selain menunjukkan tingkat kestabilan ekosistem juga sebagai indikator tingkat produktifitas perairan dan potensi perikanannya. (Nakashiuka \& Stork, 2002).

Upaya pengelolaan sumber daya di perairan Sungai Musi perlu dilakukan untuk menjaga kelestarian dan keberlanjutan pemanfaatan sumber daya perairan Sungai Musi di masa yang akan datang. Keragaman tipe ekosistem perairan, sifat pemanfatan yang multi guna dan multi sektor serta keberadaan wilayah sungai Musi yang lintas provinsi merupakan komponen yang perlu dipertimbangkan dalam pengelolaan sumber daya perairan Sungai Musi sehingga tujuan dari pengelolan tersebut tercapai secara optimal. Materi yang dijelaskan dalam makalah ini mencakup; (1) kondisi geografi dan morfologi Sungai Musi; (2) perubahan fisik lingkungan perairan atau modifikasi lingkungan; (3) penambahan bahan-bahan luar hasil kegiatan manusia di Sungai Musi saat ini; dan upaya pengelolaannya.

\section{KONDISI GEOGRAFI DAN MORFOLOGI SUNGAI MUSI}

Sungai Musi tergolong sungai besar yang bermuara ke pantai timur Pulau Sumatera. Daerah Aliran Sungai (DAS) Musi membentang diantara $1^{\circ} 40^{\prime} \mathrm{LS}$ sampai $5^{\circ} \mathrm{LS}$ dan $102^{\circ} 7^{\prime} \mathrm{BT}$ sampai 105ㄱ'BT. Wilayah DAS Musi terletak pada 3 provinsi yaitu Provinsi Bengkulu, Jambi, dan Sumatera Selatan dengan luas DAS adalah 6.006 .519 ha dan terdiri atas 10 sub DAS. Aliran induk Sungai Musi bersumber di Bukit Barisan di sekitar lereng Bukit Kelam dan Bukit Daun pada ketinggian $875 \mathrm{~m}$ di atas permukaan laut (Team Survai Ekologi Perikanan, Fakultas Perikanan IPB, 1977).
Morfologi DAS Musi dari hulu hingga hilir terbagi atas 3 tipe ekologi yaitu (1) tipe perairan berarus deras sampai sedang, (2) tipe perairan berarus tenang, dan (3) tipe perairan yang dipengaruhi pasang surut air laut. Sungai Musi bagian hulu dimulai dari sumber air di sekitar lereng Bukit Kelam dan Bukit Daun, Provinsi Bengkulu dengan ketinggian 875 dari permukaan laut (dpl) hingga Desa Muara Kelingi, Kabupaten Musi Rawas, Provinsi Sumatera Selatan dengan ketinggian \pm 40 meter dpl, dan dengan kecepatan aliran air pada kisaran 1,0-1,2 meter/detik. Panjang Sungai Musi bagian hulu $\pm 187 \mathrm{~km}$, dengan pemanfaatan lahan didominasi oleh kegiatan pertanian dan perkebunan. Batas antara Sungai Musi bagian hulu dengan Sungai Musi bagian tengah dicirikan oleh batas antara badan sungai dengan daratan sekitarnya yang masih tegas.

Sungai Musi bagian tengah dimulai dari Kecamatan Muara Kelingi, Kabupaten Musi Rawas sampai Desa Tebing Abang, Kabupaten Muara Enim, Sumatera Selatan dengan panjang sungai mencapai \pm 177 $\mathrm{km}$ dan ketinggian antara 40-15 dpl. Sekitar badan sungai banyak terdapat areal hutan rawa yang disebut rawang, antara lain di antara Muara Kelingi dan Muara Lakitan, kemudian di daerah antara Muara Rawas dan Danau Cala. Tipe ekosistem perairan yang lain terdapat pada bagian tengah Sungai Musi diantaranya adalah rawa banjiran lebak kumpai (savannah floodplain), sungai mati (oxbow lake), lebung-lebung atau cekungan di daerah rawa banjiran (floodplain pool) dan anak-anak sungai yang bermuara ke sungai utama. Ciri khas Sungai Musi bagian tengah adalah kualitas dan kuantitas air sungai sangat dipengaruhi oleh kondisi air yang berasal dari rawa banjiran (lebak dan rawang) yang ada di kiri-kanan badan sungai. 
Sungai Musi bagian hilir dimulai dari Desa Tebing Abang, Kabupaten Muara Enim hingga ke Muara Selat Bangka di Desa Sungsang, Kabupaten Banyuasin, Sumatera Selatan dengan panjang sungai mencapai $146 \mathrm{~km}$ dan ketinggian pada kisaran 0-15 dpl. Pada daerah yang berdekatan dengan muara, kondisi perairan sudah dipengaruhi kadar garam air laut yang berasal dari Selat Bangka.

\section{MODIFIKASI LINGKUNGAN DAERAH ALIRAN SUNGAI MUSI}

Modifikasi lingkungan di DAS dapat dikelompokkan pada upaya pembendungan dan pembelokan badan sungai, serta pembuatan parit-parit untuk sarana transportasi air dan irigasi. Pembendungan badan air di DAS Musi ditemukan pada badan utama Sungai Musi dan Sub-DAS Komering. Di Sungai Musi, pembendungan badan air ditemukan di bagian hulu yaitu di desa Kejalo, Kabupaten Curup, dan desa Ujan Mas Atas (Kabupaten Kepahiang) yang terletak di Kabupaten Curup, Bengkulu. Fungsi bendungan Kejalo adalah penampungan air untuk irigasi sedangkan Bendungan Ujan Mas difungsikan untuk pengadaan listrik tenaga air. Pembendungan di Sub-DAS Komering ditemukan di hulu Sungai Selabung yang merupakan anak Sungai Komering dan di badan Komering bagian hulu yang terletak di desa Perjaya, Kabupaten Ogan Komering Ulu. Kedua bendungan tersebut difungsikan untuk cadangan air irigasi.

Dampak fisik pembangunan bendungan di bagian hulu Sungai Musi (Ujan Mas) adalah terjadinya banjir dan tingginya tingkat kekeruhan air pada bagian hilir bendungan pada saat musim hujan yang bersamaan dengan dibukanya pintu air. Sebaliknya keberadaan Bendungan Irigasi Perjaya menyebabkan penurunan tinggi, volume, dan debit air, sedimentasi di bagian hilir bendungan bahkan di desa Gunung Batu (Kabupaten Ogan Komering Ulu), pada bulan Juni sampai dengan Agustus, kondisi Sungai Komering benarbenar kering.

Dampak biologis bendungan baik di badan utama Sungai Musi dan Sub-DAS Komering adalah terhalangnya migrasi pemijahan beberapa jenis ikan seperti lkan Semah (Tor doudronensis). Hasil tangkapan Ikan Semah berkurang sejak berdirinya bendungan (Husnah et al., 2007a). Walaupun bendungan Komering telah dilengkapi dengan konstruksi fish way/fish ladder, namun konstruksi fish ladder tersebut belum memungkinkan ikan untuk dapat bermigrasi dari bagian hilir bendungan menuju ke bagian hulu bendungan. Konstruksi fish ladderyang ada terdiri atas beberapa anak tangga dengan sistem pengaliran air secara buffle. Jarak antara satu anak tangga dengan anak tangga yang lain agak dekat dan pada bagian dasar dari masing-masing anak tangga tersebut tidak memiliki kedalaman cekungan yang memadai bagi ikan untuk beristirahat sementara sebelum menaiki anak tangga yang berikutnya. Ikan-ikan yang tidak dapat melalui kontruksi fish ladder akan tertahan pada lokasi tepat di bagian bawah bendungan. Walaupun lokasi tersebut merupakan lokasi terlarang untuk penangkapan ikan seperti yang tertuang dengan Undang-undang No. 9 tahun 1985 dan SK Bupati KDH OKU No.39/IV/1995, masyarakat setempat masih melakukan penangkapan ikan bahkan kadangkala masyarakat meminta penjaga pintu air untuk menutup pintu air agar mereka dapat menangkap ikan di lokasi tersebut. Hasil survey lapangan pada bulan Juni 2006 mendapatkan lebih kurang 14 nelayan sedang melakukan penangkapan ikan di lokasi tepat di bawah bendungan dengan berbagai jenis alat tangkap seperti jala (cash net), jaring hanyut (drift net), langian 
(hand operated scoop net), bahkan alat tangkap yang dilarang seperti strum

Pembelokan masa air (water diversion) di DAS Musi ditemukan di Sub-DAS Rawas yaitu di desa Bingin Teluk (Kabupaten Musi Rawas). Tujuan dari pembelokan adalah untuk mempendek jarak tempuh dari desa Bingin Teluk menuju S. Lemurus (Husnah et al., 2006). Selain di badan utama Sungai Musi, pembelokan juga terdapat di anak Sungai Musi yaitu Sungai Komering. Massa air Sungai Komering dibelokkan ke anak Sungai Musi lainnya yaitu Sungai Ogan melalui saluran di Terusan Aji, Patapahan, dan Randu yang berlokasi di Ogan Kabupaten Ogan Komering Ulu. Dampak yang ditimbulkan diantaranya adalah penurunan tinggi muka air dan debit air pada bagian hilir dari bendungan irigasi Upper Komering, dan di Sungai Lempuing berikut dengan rawa banjirannya (Husnah, 2008).

Pembuatan parit (kanal-kanal) DAS Musi banyak ditemukan di bagian hilir (Kabupaten Banyuasin) yang merupakan lokasi transmigrasi. Tujuan pembangunan kanal-kanal ini selain sebagai jalur transportasi transmigrasi juga berfungsi sebagai saluran irigasi. Sebagian besar jenis tanah pada lokasi pembukaan tanah untuk kanal tersebut tergolong tanah sulfat masam (potensial dan aktual). Dampak yang ditimbulkan pembuatan kanal ini adalah asidifikasi (pemasaman) air sungai yang berdekatan dengan kanal.

Alih fungsi lahan hutan untuk pemanfaatan lainnya dapat mempengaruhi pola hidrologi, ketinggian muka air dan debit air pada badan utama Sungai Musi dan anak-anak sungainya. Selama periode 30 tahun terjadi perubahan pemanfaatan lahan dari dominasi hutan dengan persentase $57,91 \%$ dan $53,22 \%$ dari luas total wilayah administrasi Sumatera Selatan atau
$61,39 \%$ dan $77,09 \%$ dari luas DAS Musi pada tahun 1976 menjadi pemanfaatan perkebunan (perkebunan campuran, perkebunan rakyat, dan perkebunan swasta) dengan persentase tutupan $44,64 \%$ dari luas wilayah administrasi atau $62,80 \%$ dari luas DAS Musi pada tahun 2006 (Husnah et al., 2006). Luas lahan perkebunan rakyat pada umumnya didominasi untuk semua komoditi yang diusahakan seperti karet, kopi, kelapa, dan kelapa sawit, sementara perkebunan besar diusahan kelapa sawit. Luas perkebunan kelapa sawit mencapai 488.963 ha dengan produksi 1.459.693 ton (Susanto et al., 2005).

Kegiatan perkebunan kelapa sawit tidak saja di dataran tinggi, juga dilakukan di dataran rendah di daerah rawa banjiran. Pengamatan secara selintas di sepanjang Sungai Lempuing, Kabupaten Ogan Komering Ilir menunjukkan adanya kegiatan perkebunan kelapa sawit mulai dari kecamatan Burnai hingga Lubuk Kemudi.Berdasarkan wawancara dengan staf perusahaan perkebunan, perusahaan merencanakan akan membangun kanal atau parit sepanjang $1 \mathrm{~km}$ di daerah rawa banjiran tersebut. Kegiatan-kegiatan perkebunan kelapa sawit yang dapat mempengaruhi kualitas lingkungan diantaranya adalah (a) kegiatan pembukaan lahan, (2) pengaruh dari pembangunan saluran/parit, dan (3) pasokan bahan-bahan antropogenik.

Pembukaan hutan di rawa banjiran dapat mengganggu merusak lahan gambut. Sebagian dari $8 \%$ emisi karbon global disebabkan oleh pembukaan hutan gambut untuk kegiatan perkebunan sawit baik pembukaan lahan (Anonimus, 2008).Pembangunan kanal/parit pada rawa banjiran akan mempengaruhi siklus hidrologi. Sungai dan hutan rawa akan megalami kekeringan bahkan hilang. 
Penurunan tinggi muka air akan mempengaruhi proses yang terjadi antara sungai dan rawa banjiran. Junk. (1989) menyatakan bahwa rawa banjiran adalah bio prosesor. Nutrient an organic yang dibawa dari sungai menuju rawa banjiran pada saat besar akan digunakan oleh organisme produser untuk menghasilkan bahan organik yang kemudian dimanfaatkan oleh organisme consumer baik yang ada di di daratan ataupun di perairan.

\section{JENIS DAN SUMBER BAHAN PENCEMAR}

Jenis bahan yang beracun atau tidak beracun yang masuk ke dalam suatu ekosistem perairan (bahan antropogenik) sangat berkaitan erat dengan jenis kegiatan ekonomi yang ada di daratan di lingkungan perairan. Jenis bahan antropogenik di DAS Musi dan sub-sub DAS-nya sangat bervariasi tergantung pada kondisi physiografi dan geomormologi. Pada umumnya bahan antrophogenik mulai ditemukan pada bagian tengah hingga bagian hilir dari DAS Musi dan Sub-sub DAS-nya (Husnah et al., 2006). Jenis dan sumber bahan antropogenik pada umumnya adalah bahan organik, lemak (grease) padatan tersuspensi (TSS), logam berat, organochlorine, hidrokarbon, pestisida, dan unsur hara (Tabel 1).

Keberadaan bahan antrophogenik tersebut di DAS Musi menimbulkan dampak yang bervariasi dan sangat tergantung pada jenis dan sumber bahan antrophogenik. Bahan antrophogenik yang berasal dari pengolahan kelapa, kelapa sawit seperti ditemukan desa Mandala yang termasuk dalam Sub-DAS Ogan selain meningkatkan kekeruhan bahan organik dalam air menurunkan kandungan oksigen juga berdampak terhadap kehidupan organisme air. Setelah pabrik pengolahan tersebut didirikan, jumlah hasil tangkapan ikan mengalami penurunan.

Bahan antropogenik dari pengolahan minyak bumi dan industri pupuk kimia juga mempengaruhi kehidupan biota di Sub-DAS Musi dan Sub-DAS Komering bagian hilir. Industri pengolahan (penyulingan) minyak bumi mentah merupakan salah satu industri yang ditemukan di bagian hilir sungai Musi yang dimulai dari Kelurahn Plaju llir hingga Kelurahan Sungai Gerong. Seperti kegiatan industri lainnya di sepanjang sungai Musi, limbah hasil penyulingan minyak setelah melalui proses pengelolaan limbah akan dibuang ke perairan Sungai Musi. Selain limbah hasil proses penyulingan, beberapa material input ataupun produk industri perminyakan seperti ceceran minyak bumi mentah dan olahannya dapat memasuki perairan secara tidak sengaja. Phenomena ini ditemukan pada tahun 1970-an dimana ceceran minyak bumi mentah menutupi permukaan perairan sungai Musi dalam wilayah pengolahan PERTAMINA. Kemudian pada 7 Juli 2003 pencemaran terjadi akibat tabrakan antara kapal barang Vietnam MV An Giang 05 dan kapal tongkang yang membawa minyak solar milik PT PLN sebanyak 363 kiloliter. Tabrakan terjadi di depan dermaga 8 milik Pertamina Unit Pengolahan (UP) III Plaju. Tumpahan minyak solar bercampur air memiliki ketebalan $0,3-1,5 \mathrm{~cm}$ yang mengandung PAH (Polyciclic aromatic hydrocarbons) yang sangat bersifat toksik terhadap organisme perairan (Walhi Sumsel, 2003). 
Tabel 1. Jenis dan sumber bahan antrophogenik yang dianalisis dari perairan di DAS Musi

Table 1.

\begin{tabular}{|c|c|c|c|}
\hline Sub-DAS & Sungai Utama & Kegiatan ekonomi (sumber) & Bahan Antrophogenik \\
\hline Komering & Komering & $\begin{array}{l}\text { - Pertanian/Perkebunan } \\
\text { - Pengolahan minyak bumi } \\
\text { - Pengolahan Kelapa Sawit } \\
\text { - Budidaya ikan }\end{array}$ & $\begin{array}{l}\text { - Unsur hara, pestisida } \\
\text { - Hidrokarbon (aromatik, } \\
\text { asphaltik, naftenik), TSS } \\
\text { - Bahan organik, TSS, } \\
\text { grease } \\
\text {-Bahan organik, TSS }\end{array}$ \\
\hline Lematang & Lematang & $\begin{array}{l}\text { - Pertanian/perkebunan } \\
\text { - Penambangan Batubara } \\
\text { - Pembuatan Kertas }\end{array}$ & $\begin{array}{l}\text { - Unsur hara, pestisida } \\
\text { - Logam berat (Cd, Mn) } \\
\text { TSS, } \mathrm{H}_{+} \\
\text {- Organochlorine, }\end{array}$ \\
\hline Musi Hulu & Musi Hulu & & \\
\hline Rawas & Rawas & $\begin{array}{l}\text { - Pertanian/perkebunan } \\
\text { - Penambangan Emas } \\
\text { - Pengolahan Kelapa Sawit }\end{array}$ & $\begin{array}{l}\text { - Unsur hara, pestisida } \\
\text { - Logam berat (Cd), TSS } \\
\text { - Bahan organik, TSS, } \\
\text { grease }\end{array}$ \\
\hline Lakitan & Lakitan & - & \\
\hline Ogan & Ogan & $\begin{array}{l}\text { - Pertanian/perkebunan } \\
\text { - Pengergajian kayu } \\
\text { - Pengolahan Kelapa Sawit } \\
\text { - Pengolahan karet } \\
\text { - Pengolahan gula }\end{array}$ & $\begin{array}{l}\text { - Unsur hara, pestisida } \\
\text { - TSS } \\
\text { - Bahan organik, TSS, } \\
\text { grease } \\
\text { - Bahan organik, H+ } \\
\text { - Bahan organik, TSS }\end{array}$ \\
\hline Kelingi & Kelingi & - Pertanian/perkebunan & - Unsur hara, pestisida \\
\hline Kikim & Kikim & - Pertanian/perkebunan & - Unsur hara, pestisida \\
\hline Semangus & Semangus & $\begin{array}{l}\text { - Pertanian/perkebunan } \\
\text { - Pengolahan Kelapa Sawit }\end{array}$ & $\begin{array}{l}\text { - Bahan organik, TSS, } \\
\text { grease }\end{array}$ \\
\hline $\begin{array}{l}\text { Batanghari Leko } \\
\text { Musi Hilir }\end{array}$ & $\begin{array}{l}\text { Batanghari Leko } \\
\text { Musi Hilir }\end{array}$ & $\begin{array}{l}\text { - Pertanian/perkebunan } \\
\text { - Pertanian/Perkebunan } \\
\text { - Pengolahan minyak bumi } \\
\text { - Pengolahan Kelapa dan } \\
\text { kelapa Sawit } \\
\text { - Pengergajian kayu } \\
\text { - Pengolahan karet } \\
\text { - Industri makanan dan } \\
\text { minuman } \\
\text { - Industri pupuk kimia } \\
\text { - Pemukiman }\end{array}$ & $\begin{array}{l}\text { - Unsur hara, pestisida } \\
\text { - Unsur hara, pestisida } \\
\text { - Hidrokarbon (aromatik, } \\
\text { asphaltik, naftenik), TSS } \\
\text { - Bahan organik, TSS, } \\
\text { grease } \\
\text { - TSS } \\
\text { - Bahan organik, H+ } \\
\text { - Bahan organik, TSS } \\
\text { - Urea, NH3, H+ } \\
\text { - Bahan organik, } \\
\text { Detergent }\end{array}$ \\
\hline
\end{tabular}

Tumpahan minyak kemudian terjadi kembali pada awal bulan Maret 2007 dimana terjadi kebocoran tangki penampung minyak bumi mentah PERTAMINA di kelurahan Sungai Rebo, Sumatera Selatan. tumpahan minyak bumi mentah tersebut menutupi permukaan air
Sungai Komering. Setelah satu minggu sebaran minyak masih menutupi permukaan air khususnya pada perairan yang berdekatan dengan lokasi kebocoran (Mariana, Muara Sungai Komering, S. Rebo, dan Sungai Pinang). Konsentrasi tumpahan minyak relatif lebih besar 
ditemukan pada anak tiga lokasi yaitu Mariana, Muara Sungai Komering, dan Sungai Rebo). Hal ini ditunjukkan dengan masih tertutupinya sedimen dengan lapisan minyak bumi mentah. Pada stasiun yang agak jauh dari lokasi kebocoran, lapisan minyak yang terdispesi masih ditemukan (Husnah et al., 2008). Dispersi minyak dihasilkan oleh gerakan air yang melewati tiang-tiang rumah, tembok pembatas sungai ataupun tanaman riparian yang tertutupi oleh minyak bumi mentah. Pada bagian hilir lokasi kebocoran, sebaran yang terjauh mencapai stasiun SST, sedangkan pada bagian hulunya mencapai Sungai Pinang (anak Sungai Komering). Sebaran kebocoran minyak di bagian hulu Sungai Musi tidak mencapai stasiun Pahlawan.

Pengaruh tumpahan minyak terhadap nilai parameter fisik dan kimia kualitas air kurang memberikan pola yang jelas kecuali parameter TSS, $\mathrm{pH}$, alkalinitas total, oksigen terlarut dan BOD5. Nilai TSS relatif lebih rendah pada lokasi berdekatan dengan tumpahan minyak baik (Mariana, Muara Komering, S. Rebo dan Sungai Pinang). Rendahnya nilai TSS pada beberapa stasiun ini diperkirakan pengaruh sinergis dari kebocoran minyak bumi mentah dan karakteristik fisik alami perairan Sungai Komering yang banyak dipengaruhi oleh karakteristik air rawa banjiran.

Kebocoran minyak bumi juga mempengaruhi organisma air khususnya organisma dasar perairan atau biasa disebut dengan makrozoobenthos. Kelimpahan keanekaragaman makrozoobenthos pada lokasi kebocoran lebih rendah dibandingkan dengan lokasi lainnya di Sungai Musi. Hal ini diperkirakan berkaitan penutupan sedimen oleh lapisan minyak bumi mentah. Pada saat pengambilan contoh makrozoobenthos, sedimen masih diselimuti oleh minyak bumi mentah. Hasil beberapa studi menunjukkan adanya pengaruh tumpahan minyak terhadap penutupan sedimen perairan yang akan mempengaruhi wilayah pencarian makanan organisma dasar dan akhirnya akan menurunkan kelimpahan organisma dasar

Kebocoran minyak bumi mentah juga mempengaruhi organisme lain seperti tanaman air dan ikan di perairan Sungai Musi dan Sungai Komering. Pada umumnya tanaman air yang mengapung seperti Eceng Gondok (Euchornia crassipes) dan tanaman air pinggiran sungai (riparian vegetation) diselimuti minyak bumi mentah. Tanaman Eceng Gondok dan arus pasang surut merupakan carrier penting dalam pendistribusian kebocoran minyak bumi mentah ke bagian hilir hingga hulu dari stasiun kebocoran minyak bumi mentah. Beberapa tanaman air tepian seperti di stasiun Prajen dan Prasial terlihat mati dan layu.

Kebocoran minyak bumi mentah mempengaruhi kehidupan ikan khususnya pada lokasi yang berdekatan dengan kebocoran seperti Muara Sungai Komering. Dampak yang paling dirasakannya adalah menurunnya hasil tangkapan ikan. Biasanya hasil tangkapan pada hari-hari sebelumnya dapat mencapai $20-25 \mathrm{~kg} / \mathrm{hari}$ namun sejak tumpahan minyak ini terjadi maka hasil tangkapan menurun drastik menjadi $7-13 \mathrm{~kg} /$ harinya. Jenis ikan yang tertangkap setelah terjadi tumpahan minyak ini diantaranya lkan Janggut (Polystonemus multifilis), Juaro (Pangasius polyuranodon), Coli (Albulichthys albuloides), Sepengkah (Parambassis spi), dan Bengalan (Puntioplites waandersi). Jenis ikan yang tidak tertangkap dan terlihat didaerah pencemaran adalan Ikan Seluang (Rasbora $\mathrm{sp}$ ), diduga ikan ini pada hari kedua setelah pencemaran melakukan migrasi ketempat yang tidak tercemar. 
Hasil kajian kesehatan lingkungan perairan Sungai Musi dari hulu hingga ke hilir dengan menggunakan indikator biota dasar makrozoobenthos menunjukkan bahwa perairan Sungai Musi bagian hulu hingga tengah tengah tergolong terpolusi sedang, pada bagian hilir terpolusi berat oleh bahan organik dimulai dari stasiun Gandus hingga Muara Sungai Komering (Husnah et al., 2007).

Selain makrozoobenthos, ikan dapat digunakan sebagai indikator tingkat tekanan lingkungan suatu perairan. Beberapa indikator tekanan lingkungan terhadap populasi ikan diantaranya adalah berkurangnya hasil tangkapan per unit upaya, berkuranya ukuran individu ikan, dan semakin besarnya proporsi ikan dengan trofik level non predator (herbivora, detritivora) dibandingkan jenis ikan predator. Pada sungai Musi bagian hulu proporsi jenis ikan non predator lebih banyak dibandingkan dengan ikan predator. Fenomena ini bukan dipengaruhi oleh tekanan lingkungan namun lebih banyak karena pengaruh alami dimana proporsi ikan non predator semakin berkurang dengan semakin mendekati muara sungai. Pada Sungai Musi bagian tengah, proporsi ikan predator dan non predator hampir mendekati satu sama lain (Husnah et al., 2007).

\section{UPAYA PENGELOLAAN SUMBER DAYA PERAIRAN SUNGAI MUSI}

Upaya pengelolaan sumber daya perairan dan ikan di perairan Sungai Musi tidak saja didasarkan pada UU No. 7, 2004 tentang sumber daya air namun didasarkan juga Undang-Undang No 31 tahun 2004 yang telah diperbaharuhi dengan UndangUndang No. 45 Tahun 2009 tentang perikanan, dan peraturan perundangan lainnya yang ditetapkan oleh pemerintah pusat, pemerintah provinsi dan kabupaten/ kota. Pola pengelolaan sumber daya perairan dan perikanan didasarkan pada prinsip keseimbangan antara upaya pendayagunaan dan konservasi sumber daya air. Mengingat beragam tipe ekosistem perairan di Sungai Musi, sifat pemanfatan yang multi guna dan multi sektor serta keberadaan wilayah sungah Musi yang lintas provinsi maka pola pengelolaan yang dikembangkan hendaknya secara terpadu dengan mempertimbangkan ketiga komponen tersebut.

Keterpaduan dalam perencanaan dan pengelolaan Sungai Musi mencakup empat aspek yaitu: (1) keterpaduan wilayah/ ekologis; (2) keterpaduan sektor; (3) keterpaduan ilmu; dan (4) keterpaduan stakeholder. Secara ekologis, Sungai Musi dari hulu hingga hilir merupakan satu kesatuan sedangkan secara wilayah administrasi Sungai Musi khususnya pada bagian hulu terletak pada tiga provinsi yaitu Lampung, Bengkulu, dan Sumatera Selatan. Berdasarkan Undang-Undang No. 7 tahun 2004 pasal 14, wewenang dan tanggung jawab pengelolaan wilayah sungai lintas provinsi tersebut dilakukan oleh pemerintah. Namun demikian pemerintah provinsi, kabupaten, dan kota dalam menetapkan pengelolaan sungai di wilayahnya harus mengacu pada kebijakan nasional pengelolaan sumber daya air seperti tertera pada pasal 15 dan 16 Undang-Undang No 7 tahun 2004 tersebut. Oleh karena itu setiap kegiatan yang memanfaatkan sumber daya perairan dan daratan di bagian hulu Sungai Musi seperti pembangunan bendungan untuk pembangkit listrik tenaga air di Desa Ujan Mas, Bendungan Irigasi di Desa Kejalo, dan perkebunan tanaman industri yang terletak di provinsi Bengkulu dapat memberikan dampak terhadap sumber daya perairan Sungai Musi di wilayah provinsi Sumatera Selatan. Upaya untuk mengkoordinasikan pengelolaan perairan sungai dari telah 
dilakukan dengan terbentuknya Forum Perairan Umum Indonesia, yang diprakarsai oleh Balai Riset Perikanan Perairan Umum, LIPI dan beberapa perguruan tinggi, namun sampai saat ini tujuan tersebut belum tercapai. Pengelolaan sumber daya perairan sungai masih berbasis wilayah provinsi, kabupaten atau kota. Penurunan volume dan debit air akibat pembelokan massa air di Sungai Komering diantaranya diatasi dengan penutupan pintu air pada saluran di Terusan Aji, Patapahan, dan Randu yang berlokasi di Ogan Kabupaten Ogan Komering Ulu pada musim kemarau, dan pendalaman saluran di Sungai Lempuing (KOMPAS, 2006).

Rasio antara luas kawasan hutan dan DAS Musi pada tahun 2006 mencapai $38,20 \%$ dan telah mendekati batas minimal yang telah ditetapkan dalam Keputusan Menteri Kehutanan No. 48 tahun 2004, yaitu lebih dari $30 \%$ dari luasan DAS. Untuk itu, pengelolaan kualitas dan kuantitas sumber daya perairan di Sungai Musi tidak ditujukan pada pengelolaan perairannya saja, namun harus juga dikonsentrasikan pada pengelolaan daratan karena ada kesinambungan ekologis antara ekosistem perairan dengan daratan. Pengelolaan alih fungsi lahan rawa menjadi lahan perkebunan sawit dan karet masyarakat ataupun perusahaan besar secara pesat, tidak saja didasarkan pada adanya keterpaduan wilayah dan ekologis, namun perlu mempertimbangkan keterpaduan secara sektoral baik horizontal (antar sektor) ataupun vertikal (dalam satu sektor). Pemanfaatan sumber daya alam oleh satu sektor diharapkan jangan sampai menghambat kegiatan sektor lain. Beberapa peraturan perundangan berkaitan dengan pemanfaatan dan pelestarian sumber daya air, kehutanan dan lingkungan hidup telah diterbitkan seperti Peraturan Menteri Kehutanan No. P.56/Menhut-II/2008 tentang tata cara penentuan luas areal terganggu kawasan hutan, No. P.6/MenhutII/2009 tentang pembentukan wilayah kesatuan pengelolaan hutan; Keputusan Menteri Kehutanan no. SK.48/Menhut-II/ 2004 tentang penetapankawasan hutan , perubahan status dan fungsi hutan; Peraturan Menteri Pekerjaan Umum No. 11a/PRT/M/2006 tentang kriteria dan penetapan wilayah sungai, No. 63/PRT/ 1993 tentang garis sempadan sungai, daerah manfaat sungai, daerah penguasaan sungai dan bekas sungai,; Undang-undang no 7 tahun 2004 tentang sumber daya air; dan Undang-Undang RI No. 32 tahun 2009 tentang perlindungan dan pengelolaan lingkungan hidup, namun implementasi dan pengawasan terhadap peraturan dan perundangan tersebut masih bersifat sektoral. Sebagai contoh, perencanaan pembangunan bendungan baik untuk pembangkit listrik tenaga air maupun irigasi pada badan utama Sungai Musi di provinsi Bengkulu masih belum terpadu dengan sektor perikanan, karena konstruksi bendungan belum dilengkapi konstruksi jalur ikan (fish way) untuk memijah ke bagian hulu. Pada bendungan irigasi Upper Komering konstruksi jalur ruaya telah dibangun dan telah ada koordinasi dengan sektor perikanan seperti telah dipasangnya papan pengumuman pelarangan penangkapan ikan di bagian hilir bendungan, namun pengawasan dan pemberian tindakan pidana terhadap pelanggaran belum optimal sehingga ikanikan yang berkumpul dan akan menaiki fish way terjebak dengan berbagai alat tangkap ikan.

Secara vertikal, upaya sektor perikanan menjaga kelestarian sumber daya ikan telah dilakukan dengan menetapkan daerah konservasi, menebar ikan (restocking) dan pengaturan penangkapan. Konservasi sumber daya ikan telah dilakukan oleh Gubernur Sumatera Selatan dengan diterbitkannya SK No. 398/KPTS/IV/82 
tentang penetapan tiga lokasi suaka perikanan alami di Danau Ulak Lia di Kabupaten Musi Banyuasin dengan luas 105 ha, Lebung Karangan dan Teluk Rasau di Kabupaten Ogan Komering Ilir dengan luas masing-masing 38 ha dan 108 ha (Gaffar dan Muthmainnah, 2010). Suaka perikanan buatan juga telah dilakukan dengan membangun lebung-lebung buatan di di paparan banjir Sungai Lempuing. Fungsi dari suaka perikanan adalah: melindungi habitat kritis bagi ikan; melestarikan keanekaragaman hayati; dan melestarikan dan meningkatkan produksi perikanan penangkapan. Upaya restocking ikan asli Sungai Musi seperti Ikan Jelawat (Leptobarbus hoeveni), dan Ikan Baung (Mystus nemurus) telah dilakukan oleh Dinas Perikanan Provinsi Sumatera Selatan dan kabupaten Ogan Komering Ilir. Untuk mengurangi tekanan terhadap populasi ikan dari kegiatan penangkapan ikan, alternatif pengelolaan yang dilakukan adalah pengaturan penangkapan ikan dan peningkatan produksi ikan dari kegiatan budidaya ikan. Upaya pengaturan penangkapan ikan dapat dilakukan melalui penerbitan Peraturan Daerah (PERDA) tentang pelarangan daerah penangkapan ikan seperti Undang-undang No. 9 tahun 1985 dan SK Bupati KDH OKU No.39/IV/ 1995 (Husnah et al., 2007 a), dan PERDA kabupaten Musi Banyuasin NO. 14 tahun 2005 tentang pelarangan penggunaan alat tangkap yang berbahaya seperti strum, bahan peledak dan bahan beracun. Namun pelanggaran terhadap peraturan tersebut masih ditemukan di lapangan. Untuk itu, pengawasan terhadap implementasi dari peraturan perlu dilakukan oleh aparat hukum.

Pengelolaan sumber daya perairan dapat juga menyertakan masyarakat atau biasa disebut dengan pola co-managament. Pola pengelolaan ini lebih efektif karena dengan mengikutsertakan masyarakat dalam pengelolaan akan menimbulkan rasa memiliki dan tanggung jawab masyarakat terhadap sumber daya perairan di daerahnya. Pola pengelolaan kearifan lokal seperti ini merupakan pengejewantahan aspek keterpaduan stakeholder dalam pengelolaan. Co-management sudah diaplikasikan masyarakat nelayan di berbagai kabupaten seperti Ogan Komering Ilir, Musi Banyuasin, Banyuasin, dan Ogan Komering Ulu sejak dahulu melalui kegiatan Lelang Lebak Lebung yang diadakan setiap tahun yang diselenggarakan oleh marga. Saat ini lelang Lebak Lebung diselenggarakan oleh pemerintah dan telah dilegalkan dengan PERDA Sumatera Selatan no. 6 tahun 1978 dan Surat Keputusan Gubernur 78 Kepala Daerah Tingkat I Sumatera Selatan No. 705/KPTS/ II/1982 (Gaffar \& Muthmainnah, 2010).

Sifat dan karakteristik perairan sungai yang unik dan spesifik baik karakteristik ekosistem dan sosial budaya di sekitarnya, membutuhkan pendekatan berbagai disiplin ilmu. Oleh karena itu pengelolaan perairan sungai dilakukan secara holistik dengan melibatkan berbagai disiplin ilmu esakta ataupun sosial. Penanganan dampak modifikasi lingkungan dan pencemaran terhadap sumber daya perairan Sungai Musi membutuhkan suatu wadah. Wadah tersebut telah tertuang dalam UndangUndang no. 7 tahun 2004 pasal 14 yaitu dibentuknya Dewan Sumber daya Air baik pada tingkat nasional, provinsi, kabupaten dan kota dengan wewenang melakukan pengelolaan terhadap sumber daya air. Anggota dalam Dewan tersebut hendaknya berasal dari berbagai disiplin ilmu. Sampai saat ini keberadaan dan kegiatan dewan tersebut di Sumatera Selatan belum banyak diketahui masyarakat. Pengawasan terhadap dampak modifikasi lingkungan dan pencemaran pada tingkat provinsi sebagian besar masih dilakukan oleh Badan Lingkungan Hidup pemerintah provinsi 
berkoordinasi dengan Badan Lingkungan Hidup Kementerian Lingkungan Hidup.

Berdasarkan urairan tersebut, pengelolaan sumber daya perairan di Sungai Musi hendaknya dilakukan secara terpadu dan holistik dengan mempertimbangkan beberapa aspek seperti wilayah/ekologi, sektor, bidang ilmu dan stakeholder. Namun demikian, bila setiap pemerintah kabupaten yang dilintasi oleh Sungai Musi melakukan pemanfaatan dan pengelolaan mengikuti kaedah yang diterapkan secara nasional sesuai peraturan perundangundangan, keberlanjutan pemanfaatan dan pelestraian sumber daya perairan Sungai Musi dapat dicapai.

\section{KESIMPULAN}

Perubahan pemanfaatan lahan selama periode 30 tahun mempengaruhi lingkungan Sungai Musi seperti perubahan fisik (modifikasi lingkungan) dan penambahan bahan-bahan antropogenik. Modifikasi lingkungan mulai dari pembendungan sungai untuk pembangkit listrik tenaga air dan irigasi pada bagian hulu Sungai Musi, dan pembelokan masa air pada anak Sungai Musi berdampak terhadap berkurangnya luas rawa banjiran, sedimentasi, penurunan debit air dan tinggi muka air, serta terhalangnya migrasi beberapa jenis ikan diantaranya Ikan Semah (Tor doudronensis). Penambahan bahan-bahan antropogenik yang berasal dari berbagai kegiatan industri di bagian tengah dan hilir Sungai Musi, mempengaruhi sumber daya perairan dan ikan, serta hasil tangkapan nelayan. Berdasarkan indikator biota dasar makrozoobenthos dan ikan, Sungai Musi bagian hilir dari desa kelurahan Gandus sampai dengan Muara Sungai Komering tergolong tercemar berat oleh bahan organik.

Pengelolaan sumber daya perairan di Sungai Musi hendaknya dilakukan secara terpadu dan holistik dengan mempertimbangkan beberapa aspek seperti wilayah/ekologi, sektor, bidang ilmu dan stakeholder. Namun demikian, bila setiap pemerintah kabupaten yang dilintasi oleh Sungai Musi melakukan pemanfaatan dan pengelolaan mengikuti kaedah yang diterapkan secara nasional sesuai peraturan perundang-undangan, keberlanjutan pemanfaatan dan pelestraian sumber daya perairan Sungai Musi dapat dicapai.

Pembentukan dan pemberdayaan Dewan Sumber daya Air pada tingkat nasional, provinsi, kabupaten, dan kota perlu dilakukan untuk mendukung upaya pengelolaan yang terpadu baik secara ekologi, sektor, bidang ilmu dan stakeholder.

\section{DAFTAR PUSTAKA}

Gaffar, A.K. \& D. Muthmainnah, 2010. Pengelolaan sumber daya Perikanan di Sungai Musi. Dalam Perikanan Perairan Sungai Musi, Sumatera Selatan (D.I. Hartato dan Wiadnyana, N. N.) eds. Balai Riset Perikanan Perairan Umum. Bee Publishing. Hal. 246-255.

Harian KOMPAS. 2006. Empat Kabupaten di Sumsel terancam banjir. Harian Kompas Jum'at 8 December 2006.

Husnah, E.Prianto, S.N.Aida, D.Wijaya, A.Said, Sulistiono, S.Gautama, \& Makri. 2006. Inventarisasi Jenis dan Sumber Bahan Polutan serta Parameter Biologi untuk Metode Penentuan Tingkat Degradasi Lingkungan di Sungai Musi. Laporan Tahunan. Balai Riset Perikanan Perairan Umum. Pusat Riset Perikanan Tangkap. Palembang.

Husnah, D. Wijaya \& M.N. Arsyad. 2007a. Bendungan Perjaya (upper Komering): Peran dan masalahnya terhadap sumber daya perikanan di Sungai Komering. 
Prosiding Kongres IImu Pengetahuan Wilayah Indonesia Bagian Barat tahun 2007. Palembang 3-5 Juni 2007. Kerjasama Universitas Sriwijaya dan Lembaga IImu Pengetahuan Indonesia.Hal. C.10.1-C.10.8

Husnah, E. Prianto, S. N. Aida, D. Wijaya, S. Kaban, Makri, H. Z. Dahlan \& M. Kamal,. 2007b. Penentuan tingkat degradasi dan variasi metode penentuan langkah-langkah degradasi lingkungan di perairan Sungai Musi. Balai Riset Perikanan Perairan Umum, Pusat Riset Perikanan Tangkap, Badan Riset Kelautan dan Perikanan, Departemen Kelautan dan Perikanan. Palembang.16 hal.

Husnah.2008. Potential threat to the floodplain ecosystem of Lempuing River, South Sumatra. In Fisheries ecology and management of Lubuk Lampam floodplain Musi River, South Sumatra. Hartoto, D.I., S. Koeshendradrajana, E.S. Kartamihardja, A.D. Utomo, dan Z. Nasution. Research Institute for Inland Water Fisheries, Research Centre for Capture Fisheries, Agency for Marine and Fisheries Research, Ministry of Marine Affairs and Fisheries. Hal. 149155.

Husnah, E.Prianto, D. Wijaya, S. Kaban \& S. N. Aida. 2008. Inventarisasi pengaruh tumpahan minyak bumi mentah pertamina terhadap kualitas air dan biota di sungai Musi. Prosiding Forum Perairan Umum Indonesia IV. Balai Riset Perikanan Perairan Umum, Pusat Riset Perikanan Tangkap. Hal. MA.69-MA.76

Keputusan Menteri Kehutanan No. SK.48/ Menhut-II/2004 tentang Perubahan Keputusan Menteri Kehutanan No. 70/ KPTS-II/2001 tentang Penetapan
Kawasan Hutan, Perubahan Status dan Fungsi Kawasan Hutan

Manggabarani, H. 2005. Program dan Kebijakan Pengelolaan Sumber Daya Perikanan di Perairan Umum. Dalam Prosiding Forum Perairan Umum Indonesia Ke-1. Jakarta. PRPT-BRKP: 45-48.

Nakashiuka, T. \& N. Stork. 2002. Biodiversity research methods: IBOY in Western Pacific and Asia. Kyoto University Press. Melbourne. 216 hal.

Peraturan Menteri Pekerjaan Umum No. 63/PRT/1993 tentang Garis Sempadan Sungai, Daerah Manfaat Sungai, Daerah Penguasaan Sungai dan Bekas Sungai.

Peraturan Menteri Pekerjaan Umum No. 11A/PRT/M/2006 tentang Kriteria dan Penetapan Wilayah Sungai.

Peraturan Menteri Kehutanan No. P.56/ Menhut-II/2008 tentang Tata Cara Penentuan Luas Areal Terganggu dan Areal Reklamasi dan Revegetasi untuk Perhitungan Penerimaan Negara Bukan Pajak Penggunaan Kawasan Hutan.

Peraturan Menteri Kehutanan No. P.6/ Menhut-II/2009 tentang Pembentukan Wilayah Kesatuan Pengelolaan Hutan.

Sukadi, M. F. 2005. Program dan Kebijakan Perikanan Budidaya di Perairan Umum. Dalam Prosiding Forum Perairan Umum Indonesia Ke-1. Jakarta. PRPT-BRKP: 49-56.

Sukadi, M. F. 2005. Program dan Kebijakan Perikanan Budidaya di Perairan Umum. Forum Perairan Umum Indonesia Ke-1. Jakarta.PRPT.BRKP 
Susanto, R.H. et al. 2005. Master plan Sumatera Selatan sebagai lumbung pangan. BAPPEDA Sumsel dan Universitas Sriwijaya. Palembang.

Team Survai Ekologi Perikanan, Fakultas Perikanan IPB. 1977. Survai ekologi perikanan. daerah aliran sungai:aspekaspek penyelamatan perikanan di perairan umum. Direktorat Jenderal Perikanan. Departemen Pertanian RI. Bogor. 85 hal

Undang-Undang Republik Indonesia No 31 tahun 2004 tentang Perikanan.
Undang-undang Republik Indonesia No 7 tahun 2004 tentang Sumber Daya Air.

Undang-Undang RI No. 32 tahun 2009 tentang Perlindungan dan Pengelolaan Lingkungan Hidup.

Wahana Lingkungan Hidup (Walhi) Sumatera Selatan (Sumsel). 2003. PLN bertanggung jawab pencemaran Sungai Musi. http://www.suarapembaruan.com/ News/2003/ 10/07/ Nusantar/ nusa01.htm. 10 Juli 2003. 